\title{
Morphological Characteristics and Body Composition of Elite Volleyball Players: Three Montenegrin Clubs With Most Trophies Participating in European Competitions
}

\author{
Características Morfológicas y Composición Corporal de los Jugadores de Voleibol de Élite: Tres \\ Clubes Montenegrinos con la Mayoría de los Trofeos que Participan en Competencias Europeas
}

Danilo Bojanic; Milovan Ljubojevic; Dragan Krivokapic \& Dusko Bjelica

BOJANIC, D.; LJUBOJEVIC, M.; KRIVOKAPIC, D. \& BJELICA, D. Morphological characteristics and body composition of elite volleyball players: Three Montenegrin clubs with most trophies participating in European competitions. Int. J. Morphol., 38(4):903-908, 2020.

SUMMARY: The aim of this research was to determine the differences related to morphological characteristics and body composition among volleyball players of the three most successful volleyball clubs in Montenegro. The results of the survey highligted the differences in terms of morphological characteristics and body composition of the players of VC Budva, VC Buduc'nost and VC Jedinstvo. The sample of 43 subjects was divided into three sub-samples, the sub-sample of the subjects consisting of 12 players of VC Budva, the champions of Montenegro 2018-19, the other sub-sample of 17 players of VC Buducnost, the participant in the European CEV Challenge Cup 2018-19, and the one of the examinees including 14 players of VC Jedinstvo, the champions of Montenegro in the season 2017-18. Morphological characteristics in the body composition were evaluated by a battery of 11 variables: body height, body weight, triceps skinfold, biceps skinfold, skinfold of the back, abdominal skinfold, calf skinfold, thigh skinfold, body mass index, fat percentage and muscle mass. The difference between the players of three the most successful volleyball clubs in the morphological characteristics and variables for assessing body composition were determined by ANOVA and LSD Post Hoc test. ANOVA test found statistically significant differences between these three clubs, determined by six variables that estimate the skinfolds, as well as a variable of estimated body mass index (BMI). LSD Post Hoc test found that the volleyball players of VC Budva have significantly lower values ??with regard to triceps skinfold, biceps skinfold, abdominal skinfold, calf skinfold and thigh skinfold, compared to the players of VC Buducnost and VC Jedinstvo, while in the case of variables that evaluates body mass index (BMI), volleyball players of VC Buducnost have less values compared to the players of VC Budva and VC Jedinstvo.

KEY WORDS: Volleyball players; Body composition; Morphological Characteristics.

\section{INTRODUCTION}

Contemporary volleyball is a very popular sport, as a recreational activity, but also as a professional sport which is played by a large part of both male and female population. Modern volleyball game requires for all players to have a high level of general and specific motor skills that are important for a volleyball game, for the players' positions on the field (Bojanic et al., 2016). Achieving top results in sport is closely linked to specific anthropological characteristics and physical composition of body (Carter \& Heath, 1990; Bayios et al., 2006). The top sport is increasingly being given special attention precisely on monitoring and studying physical composition and morphological characteristics of body (Ackland et al., 2012; Dopsaj et al., 2017). The results of numerous scientific studies showed that body composition can be closely associated with health problems, because it can produce complications to those athletes having low body weight or some changes in body composition due to dehydration or eating disorders. Considering the specificity of volleyball and an important fact that a large number of points is being won during the game on the net, where actions are ending in a short time, there is very significant influence of some anthropological characteristics on the success of the game (Stamm et al., 2005; Gabbett \& Georgieff, 2007). When it comes to volleyball, morphological anthropometry can provide important information regarding basic selection of prospective volleyball players, as well as information that can be used in the secondary selection - specialization ie 
BOJANIC, D.; LJUBOJEVIC, M.; KRIVOKAPIC, D. \& BJELICA, D. Morphological characteristics and body composition of elite volleyball players: Three Montenegrin clubs with most trophies participating in European competitions. Int. J. Morphol., 38(4):903-908, 2020.

determination of specific playing roles in the game (Gabbett et al., 2007; Gil et al., 2007). Anthropometric characteristics and body composition play a crucial role in expressing the motor performance of volleyball players during the game, and are crucial for achieving top results (González-Ravé et al., 2011). A large number of authors researched the anthropological characteristics in volleyball players, morphological differences between team, various playing positions, different levels of competition, precisely because they are of great importance for achieving the excellent results (Malousaris et al., 2008; Palao et al., 2008). The morphological space is defined by the longitudinal dimension of the skeleton, the transversal dimensionality of the skeleton and the mass and volume of the body. Body composition research and morphological characteristics among athletes of different sports indicates that athletes of different sports possess their own specific characteristics, mostly due to the reason that absolute size contributes a significant percentage of total variance associated with athletic success (Carvajal et al., 2012). The quality selection and recognition of the actual talent is very demanding and complex process which requires a good knowledge of anthropometry and body composition, strongly linked to the high performances in sport (Srhoj et al., 2006). VC Budva, as current champion and winner of Cup of Montenegro in the season 2018-19, played the qualification for the Champions League, and continued European path to the CEV Cup. VC Jedinstvo finished the 2018-19 season in third place, while in the 2017-18 season, was the winner of the Championship and Cup and participated in qualifying for the Champions league. The VC Buducnost was vice champion and participated in the European Challenge Cup in season 2018-19. The aim of this research was to analyze the differences in some morphological characteristics and body composition among top volleyball players, members of VC Budva, VC Buducnost and VC Jedinstvo which compete in the league of Montenegro, as well as in European competitions of different levels.

\section{MATERIAL AND METHOD}

Sample of subjects: This research was conducted on the sample of 43 respondents, who competed in the First Volleyball League of Montenegro, and was divided into three sub-samples. The first sub-sample of the subjects consisted of 12 players of VC Budva, of the average age 26.23 \pm 4.2 current champion and winner of Cup of Montenegro and participant in the qualification for the Champions League in the 2019-20 season, the other sub-sample consisted of 17 players of VC Buducnost, of the average age of 18.19 \pm 1.43 , participants in the European CEV Challenge Cup in the 2018-
19 season and the last sub-sample of the examinees consisted of 14 players of VC Jedinstvo of the average age $24.19 \pm 5.51$, the champions of the Cup and Championship winners of Montenegro and participants of qualifications for the Champions League in season 2017-18. Testing was conducted during half season. All participants signed the consent form approved, formulated in accordance with the Declaration of Helsinki.

Sample of measures: Anthropometric characteristics measurements were carried out with respect to the basic rules and principles related to the selection of measuring instruments and measurement techniques standardized in accordance with the (IBP) guidelines. For the purpose of this study, eight morphological measures have been taken: body height, body weight, triceps skinfold, biceps skinfold, skinfold of the back, abdominal skinfold, calf skinfold, thigh skinfold, and three body composition assessment variables: body mass index, fat percentage and muscle mass. Anthropometer, caliper, and measuring tape were used for morphological measurements. To evaluate the body composition, Tanita body fat scale - model BC-418MA, was used. The Tanita Scale, thanks to its athletics mode, enables athletes to closely monitor their body weight, health condition and form with all relevant parameters. The principle of this scale is based on indirect measurement of the body composition; a safe electrical signal is transmitted through the body via electrodes located in the standalone unit.

Method of data processing: The data obtained through the research were processed by descriptive and comparative statistical procedures. For each variable, central and dispersion parameters have been processed. The significance of the differences between the players of the three the most successful football clubs in the morphological characteristics and variables for assessing body composition was determined by ANOVA and LSD Post Hoc tests, with statistical significance of $p<0.05$. The data obtained in the research was processed using the application statistics program SPSS 20.0, adjusted for use on personal computers.

\section{RESULTS}

The variables for assessing morphological characteristics and body composition of subjects are shown in Table I. In this study there were significant differences between these three clubs in several variables. A significant difference was found for the triceps skinfold $(\mathrm{F}=8.06, \mathrm{p}=$ $.001)$, back skinfold $(\mathrm{F}=9.30, \mathrm{p}=.000)$, biceps skinfold $(\mathrm{F}=7.50, \mathrm{p}=.002)$, abdominal skinfold $(\mathrm{F}=22.73, \mathrm{P}=.002)$, 
calf skinfold $(\mathrm{F}=17.31, \mathrm{P}=.000)$, thigh skinfold $(\mathrm{F}=25.60$, $\mathrm{p}=.000)$, Body mass index $(\mathrm{F}=3.60, \mathrm{p}=.037)$. Table II shows descriptive data of all 43 volleyball players.

The significant differences of six skinfold and body mass index (BMI) among the volleyball players of these three clubs are shown in Figures 1 and 2. LSD Post Hoc test found that the volleyball players of VC Budva have significantly lower values with regard to triceps skinfold, biceps skinfold, abdominal skinfold, calf skinfold and thigh skinfold, while in case of skinfold back volleyball players of VC Buducnost have less values in relation to the players of VC Budva and VC Jedinstvo. In case of variable code which evaluates a body mass index (BMI) players of the VC Buducnost have a lower value in relation to the players of VC Budva and VC Jedinstvo.

Table I. Descriptive data and ANOVA of 43 volleyball players, members of the three top.

\begin{tabular}{|c|c|c|c|c|c|}
\hline & VC Budva & VC Buducnost & VC Jedinstvo & \multicolumn{2}{|c|}{ ANOVA } \\
\hline Variables & MeantSD. & Mean士SD. & MeantSD & $\mathbf{F}$ & $\mathbf{P}$ \\
\hline Body height $(\mathrm{cm})$ & $192.5 \pm 5.96$ & $192.41 \pm 5.55$ & $190.79 \pm 9$ & .27 & .765 \\
\hline Body weight (kg) & $84.92 \pm 8.51$ & $79.6 \pm 6.68$ & $84.18 \pm 8.67$ & 2.04 & .144 \\
\hline Triceps skinfold (mm) & $5.7 \pm 1.69$ & $8.37 \pm 1.83$ & $9.01 \pm 2.92$ & 8.06 & .001 \\
\hline Back skinfold (mm) & $8.84 \pm 1.53$ & $8.78 \pm 2.05$ & $11.7 \pm 2.43$ & 9.30 & .000 \\
\hline Biceps skinfold (mm) & $3.25 \pm 0.89$ & $4.21 \pm 2.01$ & $6.76 \pm 3.55$ & 7.50 & .002 \\
\hline Abdominal skinfold & $8.68 \pm 2.47$ & $9.82 \pm 2.64$ & $18.5 \pm 6.36$ & 22.73 & .000 \\
\hline Calf skinfold (mm) & $4.89 \pm 2.25$ & $8.29 \pm 2.68$ & $11.13 \pm 3.04$ & 17.31 & .000 \\
\hline Thigh skinfold (mm) & $6.99 \pm 1.05$ & $10 \pm 2.58$ & $12.74 \pm 1.93$ & 25.60 & .000 \\
\hline Body mass index $\left(\mathrm{kg} / \mathrm{m}^{2}\right)$ & $22.96 \pm 2.59$ & $21.34 \pm 2.09$ & $23.23 \pm 1.69$ & 3.60 & .037 \\
\hline Percentage of fat $(\%)$ & $10.28 \pm 4.04$ & $11.57 \pm 5.05$ & $13.21 \pm 2.39$ & 1.71 & .194 \\
\hline Muscle mass (kg) & $43.03 \pm 3.57$ & $39.59 \pm 4.72$ & $41.71 \pm 5.15$ & 2.08 & .138 \\
\hline
\end{tabular}

Table II. Descriptive data of all 43 volleyball players.

\begin{tabular}{lcccr}
\hline Variable & $\mathrm{N}$ & Min & Max & \multicolumn{1}{c}{ Mean \pm SD } \\
\hline Age & 4 & 16.3 & 32.6 & $22.56 \pm 5.08$ \\
Body height $(\mathrm{cm})$ & 4 & 178. & 210. & $191.91 \pm 6.83$ \\
Body weight $(\mathrm{kg})$ & 4 & 64.7 & 99.8 & $82.58 \pm 8.08$ \\
Triceps skinfold $(\mathrm{mm})$ & 4 & 3.1 & 14.4 & $7.83 \pm 2.56$ \\
S kinfold of the back $(\mathrm{mm})$ & 4 & 6.2 & 16.1 & $9.75 \pm 2.43$ \\
Biceps skinfold $(\mathrm{mm})$ & 4 & 2.3 & 18.1 & $4.77 \pm 2.79$ \\
Abdominal skinfold $(\mathrm{mm})$ & 4 & 6.0 & 28.1 & $12.33 \pm 5.99$ \\
Calf skinfold $(\mathrm{mm})$ & 4 & 2.4 & 18.2 & $8.27 \pm 3.59$ \\
Thigh skinfold $(\mathrm{mm})$ & 4 & 5.1 & 16.2 & $10.05 \pm 3.01$ \\
Body mass index $(\mathrm{kg} / \mathrm{m} 2)$ & 4 & 17.9 & 27.9 & $22.41 \pm 2.25$ \\
Fat percentage $(\%)$ & 4 & 2.7 & 21.8 & $11.74 \pm 4.14$ \\
Muscle mass $(\mathrm{kg})$ & 4 & 30.9 & 48.7 & $41.24 \pm 4.70$ \\
\hline
\end{tabular}

\section{DISCUSSION}

The significance of body composition is a very important factor in the creation the profile of athletes who will participate at all levels of competition in top-level sport, so the access to the anthropometric characteristics of the player, and their difference will be of great help to the trainer, for better planning and training programming (Silvestre et al., 2006). The current study was conducted on top volleyball players of the highest ranking competition in Montenegro. Based on the obtained mean values of results we can conclude that there are significant differences between the three clubs. ANOVA showed statistically significant differences in 7 variables, 6 variables of skinfolds and 1 variable of BMI. LSD post hoc test showed that the volleyball players of VC Budva, have significantly lower mean values at 5 skinfolds than the team VC Buducnost $(\mathrm{p}<.001)$ and VC Jedinstvo ( $p<.001)$, except for skinfold of the back where team VC Buducnost and VC Budva are at lower level compared to VC Jedinstvo which is at level $(\mathrm{p}<.001)$. When it comes to a variable that evaluates BMI, we notice that all three teams have approximately the same 

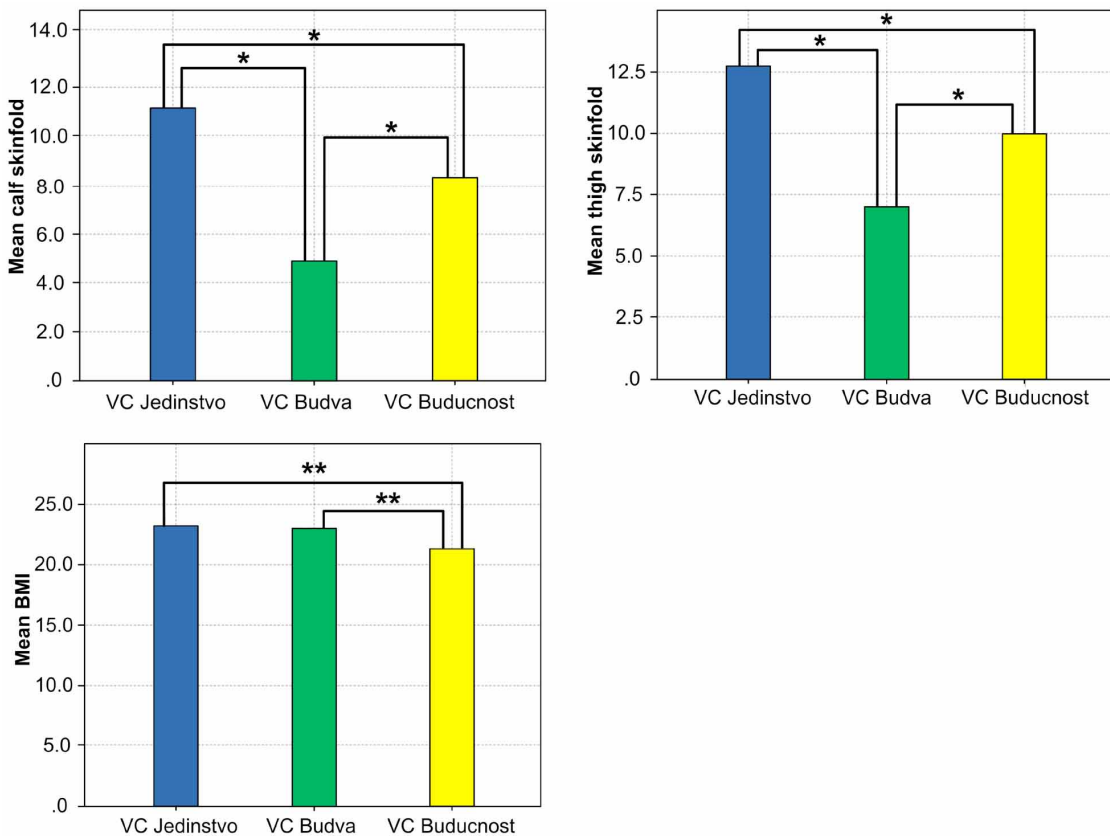

Fig.1. LSD Post Hoc test for the different parameters evaluated. $*=$ significance $\leq 0.01$; $* *=$ significance $\leq 0.05$.
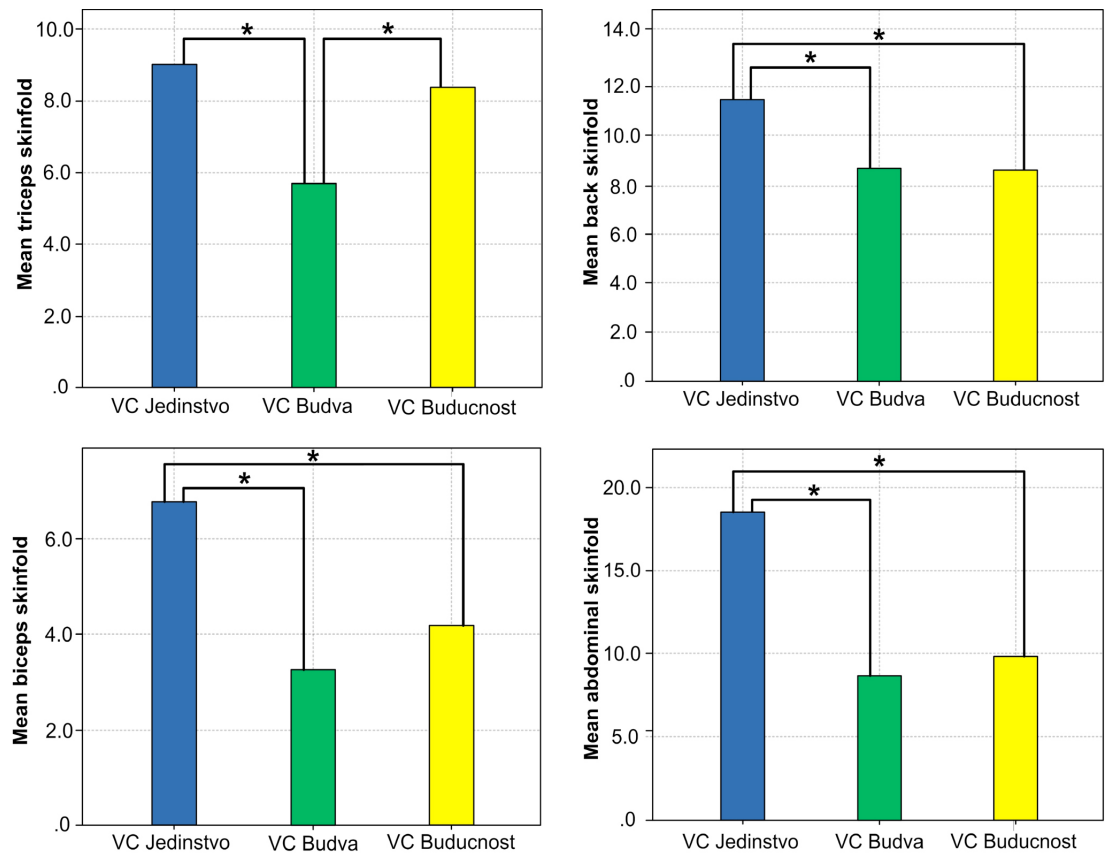

Fig. 2. LSD Post Hoc test for the different parameters evaluated. $*=$ significance $\leq 0.01$; $* *$ significance $\leq 0.05$. mean values of height, as one very important factor in top volleyball between these three clubs, we will notice that players of VC Budva and VC Buducnost have the same values, while the players of VC Jedinstvo slightly lower. These results are not surprising considering fact that the team of VC Budva has several international players who come from strong European Volleyball League, while the team VC Buducnost and VC Jedinstvo mainly consists of domestic players who create squad from their own base. Having compared the results of body fat percentage in male volleyball players in Montenegro, we realized that the volleyball players VC Budva have lower values, but not at a statistically significant level when compared to the teams VC Buducnost and VC Jedinstvo. When it comes to the muscle mass percentage averages in the Montenegrin male volleyball players, it can be concluded that the values significantly differ and that the results obtained at the players of $\mathrm{VC}$ Budva were the highest. The aforementioned can be explained by the fact that the VC Budva team is selected to play a higher level of competition than the other teams, and therefore is composed of a large number of international players who are different from the domestic players not only in terms of agility performances, but also in terms of body composition and morphological characteristics. Research conducted by Popovic et al. (2014), with elite volleyball players from the volleyball premier league in Serbia, shows the following values: that the middle value of the height $(198.5 \mathrm{~cm})$, BMI $(23.52$ $\left.\mathrm{kg} / \mathrm{m}^{2}\right)$, muscle mass $(43.6 \mathrm{~kg})$ and fat percentage (13.57\%). In Montenegro's most awarded clubs there are similar mean values of body mass index, mean values and they are in the area of normal weight, Volleyball players of VC Buducnost whose playing squad is the youngest had a lower values than players of VC Budva $(\mathrm{P}<.037)$ and $\mathrm{VC}$ Jedinstvo $(\mathrm{P}<.037)$. If we compare the percentage of body fat was significantly lower than in volleyball clubs from the premier league of Serbia, when it comes to muscle mass Montenegrin volleyball players have higher values, while the Montenegrin volleyball players are 
BOJANIC, D.; LJUBOJEVIC, M.; KRIVOKAPIC, D. \& BJELICA, D. Morphological characteristics and body composition of elite volleyball players: Three Montenegrin clubs with most trophies participating in European competitions. Int. J. Morphol., 38(4):903-908, 2020.

slightly lower compared to volleyball clubs from Serbia. If we compare the individual results of the most trophies volleyball club in Montenegro VC Budva, current champion, and team VC Vojvodina from Serbia -champions of Superleague in season 2018-19, we notice that the players of VC Vojvodina are taller $(194.24 \mathrm{~cm})$, and have a smaller level of body fat $(8.56 \%)$, as well as lower values of skinfold of the back $(4.68 \mathrm{~mm})$, but players of VC Budva have a lower value with regard to biceps skinfolds, triceps skinfold and thigh skinfold.

In the research conducted by Muniz et al. (2017), on the top volleyball players in the Brazilian first division, there is a mean value when it comes to height $(193.8 \mathrm{~cm})$ and the mean value of the weight $(84.9 \mathrm{~kg})$ while the mean value of the height and weight is slightly lower in Montenegrin volleyball players (Table II). When it comes to the mean values of percentage of fat, it is interesting that the Brazilian volleyball players have a higher fat percentage (16.4\%) compared to volleyball players of the first Montenegrin league that is mainly composed of local players, with the exception of VC Budva which has several international players. If we compare the mean values od skinfolds of Brazilian and Montenegrin Super League players in the following variables: biceps $(5.2 \%)$, triceps $(10.9 \%)$, back $(11.8 \%)$, abdominal $(15.3 \%)$, thigh $(12.9 \%)$ and calf $(9.4$ $\%$ ), we can conclude that the players of the three mentioned team in Montenegro have lower values (Table II) which is a very good result considering the fact that Montenegro has 625,000 inhabitants only, and less data base for selection of the volleyball players.

Results of the research conducted by the Medeiros et al. (2010), with Brazilian players, when comparing the average height of the Brazilian players it amounts $(194 \mathrm{~cm})$ it is slightly higher than the average height of Montenegrin players, the difference is evident at body fat percentage 8.7 \pm 4.2 for Brazilian volleyball players, while the values of skinfolds are very similar, the value of abdominal skinfold is $12.5 \pm 3.4$, back skinfold is $11.4 \pm 2.3$, thigh skinfold is $10.8 \pm 3.3$.

Excess body fat is a burden that negatively affect sports performance, which can lead to an increased need for energy and therefore to the creation of faster tiredness and reduced efficiency of athletes (Noutsos et al., 2018). Highquality estimation of body composition in the sport is a very important aspect, considering that the errors in body composition can lead to poor conception of the training process and bad meal plan which affects the achievement of superior results (de Oliveira-Junior et al., 2016). Based on studies carried out by the authors the body composition of Turkish volleyball players (Aytek, 2007), we have an avera- ge height $(198.3 \mathrm{~cm})$, BMI $(23.3 \mathrm{~kg} / \mathrm{m} 2)$, fat percentage $(9.76$ $\%)$, muscle mass $(43.09 \mathrm{~kg}$ ), so if we compare these values with the average values of Montenegrin players (Table II), we can see that the players from the Montenegro Super League have a lower average height, a greater value of body fat, BMI is similar to the values of Turkish players, and less values of muscle mass. If we compare the values of the muscular mass of volleyball players in Montenegro with studies focused on this problem (Aytek; Popovic et al.; Muniz et al.), we notice that the average values of the muscle mass are very similar, so statistics show that the Montenegrin volleyball players in this variable do not deviate from the volleyball players in the world. To what extent is muscle mass an important factor for the development of strength and performance in sports shows studies that have been conducted by Nikolaidis \& Vassilios Karydis (2011). Regarding the average height of the best volleyball players in Montenegro and when we compare them with the average results of the world's best volleyball teams such as Brasil $(194.4 \mathrm{~cm})$, Italy $(195.81 \mathrm{~cm})$, Russia $(201.81 \mathrm{~cm})$, Argentina $(194.75 \mathrm{~cm})$, USA $(196.2 \mathrm{~cm})$, Spain $(195.9 \mathrm{~cm})$, Netherland $(198.7 \mathrm{~cm})$, Cuba $(197.3 \mathrm{~cm})$, Poland $(200.0 \mathrm{~cm})$, Australia $(197.8 \mathrm{~cm})$ we notice that players of our three best clubs are still lagging behind the best world's players, which is not surprising considering that these are the world's best selection which have a much larger player base than Montenegro, where diagnostics and selection process of players in the younger age works on much better way. European anthropologists have proven that the highest people live in the Dinarides of the mountainous part of which Montenegro (Pineau et al., 2005), so, in Montenegro, special attention should be paid to sports (basketball, volleyball, handball) in which the longitudinal domain of athletes is very an essential factor in achieving superior results. These results could be helpful to the other clubs and coaches in Montenegro, dealing with the selection and planning of the training process, in order to have an insight on the levels of their athletes, and also to have some model characteristics and good guidance for creating top young volleyball players. One of the next researches will be focused on analyzing differences between these clubs in body composition and morphological characteristics in relation to the position they cover in the team, as they have a different constitution, which can be used for better selection and targeting of players for the appropriate role in a team.

\section{ACKNOWLEDGEMENTS}

We thank the players and the staff of the three volleyball clubs in Montenegro for their cooperation during this research. 
BOJANIC, D.; LJUBOJEVIC, M.; KRIVOKAPIC, D. \& BJELICA, D. Características morfológicas y composición corporal de los jugadores de voleibol de élite: Tres clubes montenegrinos con la mayoría de los trofeos que participan en competencias europeas. Int. J. Morphol., 38(4):903-908, 2020

RESUMEN: El objetivo de esta investigación fue determinar las diferencias relacionadas con las características morfológicas y la composición corporal entre los jugadores de voléibol de los tres clubes de voleibol más exitosos de Montenegro. Los resultados de la encuesta destacaron las diferencias en términos de características morfológicas y composición corporal de los jugadores de VC Budva, VC Buducnost y VC Jedinstvo. La muestra de 43 sujetos se dividió en tres submuestras, la submuestra de las asignaturas consistió en 12 jugadores de VC Budva, los campeones de Montenegro 2018-19, la otra submuestra de 17 jugadores de VC Buducnost, el participante en la European CEV Challenge Cup 2018-19, y uno de los examinados, incluidos 14 jugadores de VC Jedinstvo, campeones de Montenegro en la temporada 2017-18. Las características morfológicas en la composición corporal se evaluaron mediante una batería de 11 variables: altura corporal, peso corporal, pliegue cutáneo del tríceps, pliegue cutáneo del bíceps, pliegue cutáneo de la espalda, pliegue abdominal, pliegue cutáneo de la pantorrilla, pliegue cutáneo del muslo, índice de masa corporal, porcentaje de grasa y masa muscular. . La diferencia entre los jugadores de los tres clubes de voleibol más exitosos en las características morfológicas y las variables para evaluar la composición corporal, se determinó mediante pruebas de ANOVA y LSD Post Hoc. La prueba ANOVA encontró diferencias estadísticamente significativas entre estos tres clubes, determinadas por seis variables que estiman los pliegues cutáneos, así como una variable de índice de masa corporal (IMC) estimado. La prueba LSD Post Hoc encontró que los jugadores de voleibol de VC Budva tienen valores significativamente más bajos con respecto al pliegue de tríceps, pliegue de bíceps, pliegue abdominal, pliegue de pantorrilla y pliegue de muslo, en comparación con los jugadores de VC Buducnost y VC Jedinstvo, mientras que en el caso de Las variables que evalúan el índice de masa corporal (IMC), los jugadores de voléibol de VC Buducnost tienen menos valores, en comparación con los jugadores de VC Budva y VC Jedinstvo.

PALABRAS CLAVE: Jugadores de voleibol; Composición corporal; Características morfológicas.

\section{REFERENCES}

Ackland, T. R.; Lohman, T. G.; Sundgot-Borgen, J.; Maughan, R. J.; Meyer, N. L.; Stewart, A. D. \& Müller, W. Current status of body composition assessment in sport: review and position statement on behalf of the ad hoc research working group on body composition health and performance, under the auspices of the I.O.C. Medical Commission. Sports Med., 42(3):22749, 2012.

Aytek, A. I. Body composition of Turkish volleyball players. EAA Summer School eBook, 1:203-8, 2007.

Bayios, I. A.; Bergeles, N. K.; Apostolidis, N. G.; Noutsos, K. S. \& Koskolou, M. D. Anthropometric, body composition and somatotype differences of Greek elite female basketball, volleyball and handball players. J. Sports Med. Phys. Fitness, 46(2):271-80, 2006.

Bojanic, D.; Bjelica, D. \& Georgiev, G. Influence of a basic motor potential on the realization of specific motor skills of elite female volleyball players. $J$. Phys. Educ. Sport, 16(2):500-4, 2016

Carter, J. E. L. \& Heath, B. H. Somatotyping-Development and Application. Cambridge, Cambridge University Press, 1990.
Carvajal, W.; Betancourt, H.; León, S.; Deturnel, Y.; Martínez, M.; Echevarría, I.; Castillo, M. E. \& Serviat, N. Kinanthropometric profile of Cuban women Olympic volleyball champions. MEDICC Rev., 14(2):16-22, 2012.

de Oliveira-Junior, A. V.; Casimiro-Lopes, G.; Donangelo, C. M.; Koury, J. C.; Farinatti, P. T. V.; Massuça, L. \& Fragoso, I. Methodological agreement between body-composition methods in young soccer players stratified by zinc plasma levels. Int. J. Morphol., 34(1):49-56, 2016.

Dopsaj, M.; Markovic, M.; Kasum, G.; Jovanovic, S.; Koropanovski, N.; Vukovic, M. \& Mudric, M. Discrimination of different body structure indexes of elite athletes in combat sports measured by multi frequency bioimpedance method. Int. J. Morphol., 35(1):199-207, 2017.

Gabbett, T. \& Georgieff, B. Physiological and anthropometric characteristics of Australian junior national, state, and novice volleyball players. J. Strength Cond. Res., 21(3):902-8, 2007.

Gabbett, T.; Georgieff, B. \& Domrow, N. The use of physiological, anthropometric, and skill data to predict selection in a talent-identified junior volleyball squad. J. Sports Sci., 25(12):1337-44, 2007.

Gil, S.; Gil, J.; Ruiz, F.; Irazusta, A. \& Irazusta, J. Physiological and anthropometric characteristics of young soccer players according to their playing position: relevance for the selection process. J. Strength Cond. Res., 21(2):438-45, 2007.

González-Ravé, J. M.; Arija, A. \& Clemente-Suarez, V. Seasonal changes in jump performance and body composition in women volleyball players. J. Strength Cond. Res., 25(6):1492-501, 2011.

Malousaris, G. G.; Bergeles, N. K.; Barzouka, K. G.; Bayos, I. A.; Nassis, G. P. \& Koskolou, M. D. Somatotype, size and body composition of competitive female volleyball players. J. Sci. Med. Sport, 11(3):337-44, 2008.

Medeiros, A. I. A.; Mesquita, I.; Oliveira, J.; Loureiro, A. C. C.; Afonso, J.; Monteiro, L. Z. \& Castro, J. M. Body composition of Brazilian beach volleyball players. Br. J. Sports Med., 44(14):i17, 2010.

Muniz, Y. G.; Cossio-Bolaños, M.; Gómez-Campos, R.; Gonçalves, E. M.; Lázari, E.; Urra-Albornoz, C. \& de Arrua, M. Estimate of body fat percentage in male volleyball players: Assessment based on skinfolds. J. Exerc. Physiol., 20(3):14-24, 2017.

Nikolaidis, P. T. \& Vassilios Karydis, N. Physique and body composition in soccer players across adolescence. Asian J. Sports Med., 2(2):75-82, 2011.

Noutsos, K. S.; Rousanoglou, E. N.; Panagiotis, M. G.; Bayios, I. A. \& Boudolos, K. Performance indicators and competition ranking in women's and men's World Handball Championship 2017. J. Phys. Educ. Sport, 18(3):1761-6, 2018.

Palao, J. M.; Gutiérrez, D. \& Frideres, J. E. Height, weight, Body Mass Index, and age in beach volleyball players in relation to level and position. J. Sports Med. Phys. Fitness, 48(4):466-71, 2008.

Pineau, J. C.; Delamarche, P. \& Bozinovic, S. Average height of adolescents in the Dinaric Alps. C.R. Biol., 328(9):841-6, 2005.

Popovic, S.; Bjelica, D.; Jaksic, D. \& Hadzic, R. Comparative study of anthropometric measurement and body composition between elite soccer and volleyball players. Int. J. Morphol., 32(1):267-74, 2014.

Silvestre, R.; Kraemer, W. J.; West, C.; Judelson, D. A.; Spiering, B. A.; Vingren, J. L.; Hatfield, D. L.; Anderson, J. M. \& Maresh, C. M. Body composition and physical performance during a National Collegiate Athletic Association Division I men's soccer season. J. Strength Cond. Res., 20(4):962-70, 2006.

Srhoj, V.; Rogulj, N.; Zagorac, N. \& Katic', R. A new model of selection in women's handball. Coll. Antropol., 30(3):601-5, 2006.

Stamm, R.; Stamm, M. \& Thomson, K. Role of adolescent female volleyball players' psychophysiological properties and body build in performance of different elements of the game. Percept. Mot. Skills, 101(1):108-20, 2005.

Corresponding author:

Danilo Bojanic, PhD, Assistant Professor

Faculty for Sport and Physical Education

University of Montenegro

81400, Niksic

MONTENEGRO

Received: 11-02-2020

Accepted: 23-03-2020

Email: danilo.bo@ucg.ac.me 